\title{
Size fractionated metabolism of coastal microbial plankton*
}

\author{
Charles S. Hopkinson, $\mathrm{Jr}^{1}{ }^{1}$, Barry Sherr ${ }^{1}$, William J. Wiebe ${ }^{2}$ \\ ${ }^{1}$ University of Georgia, Marine Institute, Sapelo Island, Georgia 31327, USA \\ ${ }^{2}$ University of Georgia, Department of Microbiology, and Institute of Ecology, Athens, Georgia 30602, USA
}

\begin{abstract}
The quantitative significance of microbial heterotrophs in overall plankton metabolism was investigated in estuarine and coastal waters off the Georgia coast (USA). Three size classes were examined: $<208 \mu \mathrm{m},<10 \mu \mathrm{m}$ and $<1 \mu \mathrm{m}$. Respiration was measured by monitoring the rate of oxygen consumption in water samples incubated at in situ temperatures in the dark. Rates by all size classes of plankton were highest in the upper reaches of the Duplin River estuary during summer $\left(52.4 \mu \mathrm{g} \mathrm{O} \mathrm{O}_{2} \mathrm{l}^{-1}\right.$ $\left.\mathrm{h}^{-1}\right)$ and lowest $10 \mathrm{~km}$ offshore during winter $\left(10.1 \mu \mathrm{g} \mathrm{O} \mathrm{O}^{-1} \mathrm{~h}^{-1}\right)$. Respiration by organisms passing a $1 \mu \mathrm{m}$ screen exceeded rates in $208 \mu \mathrm{m}$ and $10 \mu \mathrm{m}$ filtered samples, but this enhancement decreased with increasing distance offshore. This increased bacterial $(<1 \mu \mathrm{m})$ respiration could not be attributed to artifacts of the filtration procedure or to bacterial growth. Respiration results were consistent with concurrently conducted studies of bacterioplankton growth and bactivorous microprotozoan grazing Static models of carbon and nitrogen flow between bacterioplankton and heterotrophic protozoa suggest that the $\mathrm{C} / \mathrm{N}$ ratio of the bacterial food source could largely dictate organic carbon conversion efficiency of planktonic bacteria, the relative role of bacteria and microprotozoans as recyclers of nitrogen and the rate of organic carbon utilization. The relative importance of bacterial nitrogen remineralization decreases as the $\mathrm{C} / \mathrm{N}$ ratio of the organic substrate increases. Results of this study are discussed in context of the microbial loop and the trophic flow leading to higher organisms
\end{abstract}

\section{INTRODUCTION}

The quantitative significance of microbial heterotrophs in overall plankton metabolism and marine food webs has received considerable attention over the past 2 decades (e.g. Pomeroy 1974, Hobbie \& Williams 1984, Berman 1988). While there is increasing evidence that bacteria and protozoa can metabolize large amounts of the daily primary production, there is little unanimity about the overall magnitude of these processes. Cushing \& Walsh (1976) considered bacteria unimportant in oceanic food webs; Steele \& Frost (1977) suggested that $<10 \%$ of the organic matter in the sea is processed by bacteria. On the other hand, Pace et al. (1984) and Williams (1984) have proposed that microbial hetero-

\footnotetext{
- Contribution No. 619 from the University of Georgia Marine Institute. This work is a result of research sponsored by NOAA, Office of Sea Grant, Department of Commerce. under grant No. NABOAA-D-00091, and by NSF under grant Nos. OCE-8700456 and BSR-8615503. The US government is authorized to produce and distribute reprints for governmental purposes notwithstanding any copyright notation that may appear hereon
}

trophs intercept and oxidize a large proportion of primary production. The matter is far from settled; as Williams (1981) and Wright \& Coffin (1984) explicitly state, caution must be taken in extrapolating results taken from one environment at one time.

A variety of methods have been used to assess the contribution of heterotrophic microbial components to total marine community metabolism and food webs (e.g. Wiebe \& Smith 1977, Hagström et al. 1979, Williams 1981, Moriarty 1984, Wright 1984, Wright \& Coffin 1984). Of these techniques, the measurement of system respiration has several advantages; it provides a rapid and simple assessment of heterotrophic metabolism which can be directly related to the oxidation of organic matter. Modern, sensitive electrode systems (e. g. Smith \& Horner 1982) and high precision Winkler determinations (Williams \& Jenkinson 1982, Griffith 1988) have made oxygen measurements amenable even to open ocean studies.

In this paper we examine the microbial contribution to planktonic respiration in estuarine and nearshore waters off Sapelo Island, Georgia, USA. Specifically, we examine 3 fractions of planktonic respiration contri- 
buted by heterotrophic microorganisms, how these fractions change across an estuarine to nearshore transect and whether bacterial respiration is controlled by grazers. Finally, we discuss the role of microorganisms in energy flow and nitrogen recycling of the nearshore and continental shelf ecosystems, and the possible consequences that an exceedingly active microbial loop might have on trophic flows leading to higher organisms.

\section{SITE DESCRIPTION}

Sites were chosen within estuarine and oceanic water bodies adjacent to Sapelo Island, Georgia (USA) for the study of size fractionated plankton metabolism (Fig. 1). Two oceanic sites are within the shallow-water $(<15 \mathrm{~m})$, nearshore region of the continental shelf in the Georgia Bight: an inner site $(1.6 \mathrm{~km}$ offshore) characterized by active estuarine plume movement, high suspended solids and organic carbon concentrations and high water turbidity, and an outer site (10 km offshore) characterized by lower concentrations of suspended solids and relatively low water turbidity. The entire nearshore region is heterotrophic $(P: R<1)$ and dependent on significant organic matter inputs from the adjacent estuaries (Hopkinson 1985), but these inputs decrease in magnitude and importance in the offshore direction.

The 2 estuarine sites are within the Duplin River, which is a pristine, major, tidal creek with a salt marsh drainage basin (Pomeroy \& Wiegert 1981). The Duplin River is highly heterotrophic (Frankenburg 1976, Wiegert \& Wetzel 1979, Hopkinson \& Hoffman 1984), generally more so in the headwaters which flood the marsh regularly than at the mouth (Imberger et al. 1983). Primary productivity averaging about 250 to $350 \mathrm{gC} \mathrm{m}^{-2} \mathrm{yr}^{-1}$ (Sherr, Whitney \& Pomeroy pers. comm.) is lower than in the adjacent nearshore region (450 to $600 \mathrm{gC} \mathrm{m}^{-2} \mathrm{yr}^{-1}$; Thomas 1966 ).

\section{MATERIALS AND METHODS}

Water samples were collected approximately monthly (1983/84) from the nearshore region but only during summer and winter from the Duplin River. A total of 39 sample collections were approximately evenly divided among the 4 sampling locations, with the exception of the lower Duplin River station which was only sampled during late summer. Water was collected only at slack low tide in the Duplin River, while in the offshore region it was collected regardless of tidal stage. At the time of collection the water was

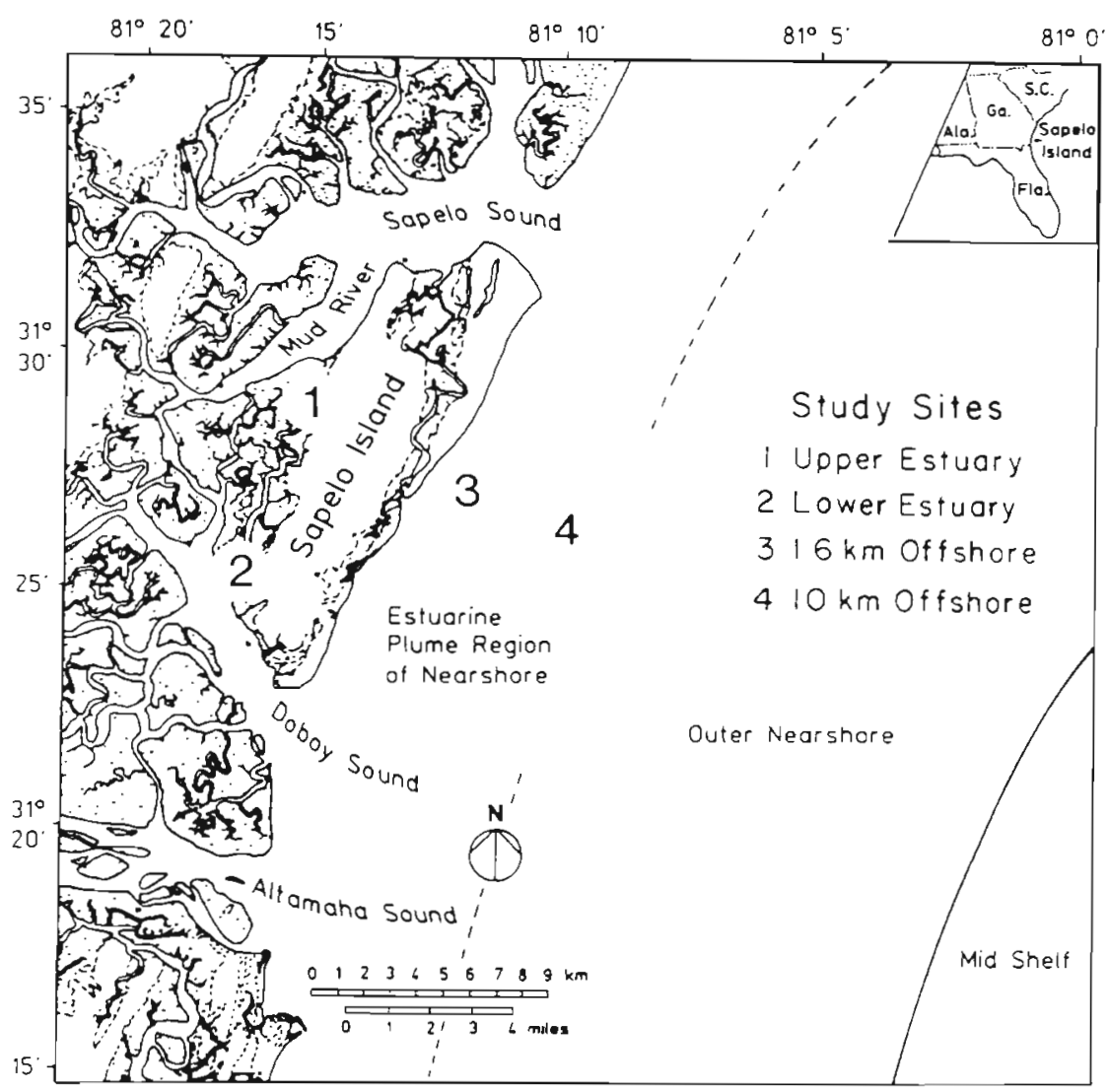

Fig. 1. Georgia coast (USA) showing sampling sites within the estuary and the nearshore region 
screened through $208 \mu \mathrm{m}$ nitex screening (DuPont woven monofilament - Tetko Inc., Elmsford, NY, USA). Size fractionation of water samples was similar to the reverse filtration procedure described by Wiebe \& Smith (1977) and Williams (1981). Within 1 h of sampling, water, collected in 12 or 20 l containers, was gently agitated with a magnetic stirrer, and back-filtered with less than $7 \mathrm{~cm}$ head through a $20 \mathrm{~cm}$ diameter filtering tube with 1 or 10 m nitex screening attached across one end. All equipment was thoroughly acid washed and leached.

Respiration was measured by monitoring the rate of oxygen consumption in samples incubated at in situ temperatures in the dark in $300 \mathrm{ml} \mathrm{BOD}$ bottles. Dissolved oxygen was measured with Orbisphere Laboratories (Geneva, Switzerland) polarographic oxygen electrodes with self-contained stirrers that were calibrated against water-saturated air

After preliminary observations showed enhanced respiration in $1 \mu \mathrm{m}$ screened water, additional experiments were designed to evaluate the physical effect of screening on substrate concentration (Ferguson et al. 1984) and the effect of potential substrate addition due to screening on respiration. Determination of the effect of reverse filtration on the concentration of available substrate was made by measuring the concentration of $\mathrm{NH}_{4}{ }^{+}$and primary amines in water before and after filtering. $\mathrm{NH}_{4}{ }^{+}$was measured with the phenolhypochlorite procedure (Grasshoff 1983), and primary amines were measured with the fluorescamine technique described by North (1975) for coastal waters. Sensitivity of the techniques is $0.05 \mu \mathrm{M}$ for $\mathrm{NH}_{4}^{+}$and $0.2 \mu M$ glycine equivalents for primary amines.

The potential stimulatory effect of increased substrate availability on respiration and a first order assessment of the potential for carbon and nitrogen limitation of the heterotrophic pelagic community were determined by comparing respiration in water with and without glucose or $\mathrm{NH}_{4}{ }^{+}$addition. For each water mass sampled, sufficient glucose $(1 \mathrm{ml})$ was added to 2 bottles of water from each size class immediately after the initial determination of oxygen concentration to raise the ambient dissolved organic carbon concentration by $1 \mathrm{mgC}^{-1}$. Dissolved organic carbon concentrations range from about $8 \mathrm{mg} \mathrm{l}^{-1}$ in the Duplin to about $3 \mathrm{mg} \mathrm{l}^{-1}$ offshore (Wheeler 1976). The effect of $\mathrm{NH}_{4}{ }^{+}$ addition was assessed only once in upper Duplin River water during winter. $\mathrm{NH}_{4}{ }^{+}$was added in sufficient quantity to raise the ammonium concentration by $1 \mu \mathrm{M}$. $\mathrm{NH}_{4}{ }^{+}$concentrations in the upper Duplin River range from less than $0.1 \mu M$ to $10 \mu M$ (Imberger et al. 1983, Chalmers pers. comm.).

Oxygen consumption (respiration) was calculated by linear least squares regression of concentration versus time. Comparisons between respiration rates (substrate additions, size class, station, season) were by standard analysis of variance (SPSS Inc.) and by the $\mathrm{T}^{\prime}$ and GT 2 methods (Sokal \& Rohlf 1969) for multiple slopes. To increase degrees of freedom available for some statistical tests, samples were grouped by water temperature, above and below $20^{\circ} \mathrm{C}$. These 2 groups are hereafter designated as either summer or winter groups.

\section{RESULTS AND DISCUSSION}

\section{Time course changes in dissolved oxygen concentration}

A typical data set is presented to illustrate general treatment effects and the manner in which dissolved oxygen concentration (DO) decreased over time (Fig. 2). This particular data set, collected in April from the site $1.6 \mathrm{~km}$ offshore, was representative of the gen-
Fig. 2. Time course of dissolved oxygen concentration in size fractionated water with and without glucose amendment. Water collected from $1.6 \mathrm{~km}$ in April, 1984

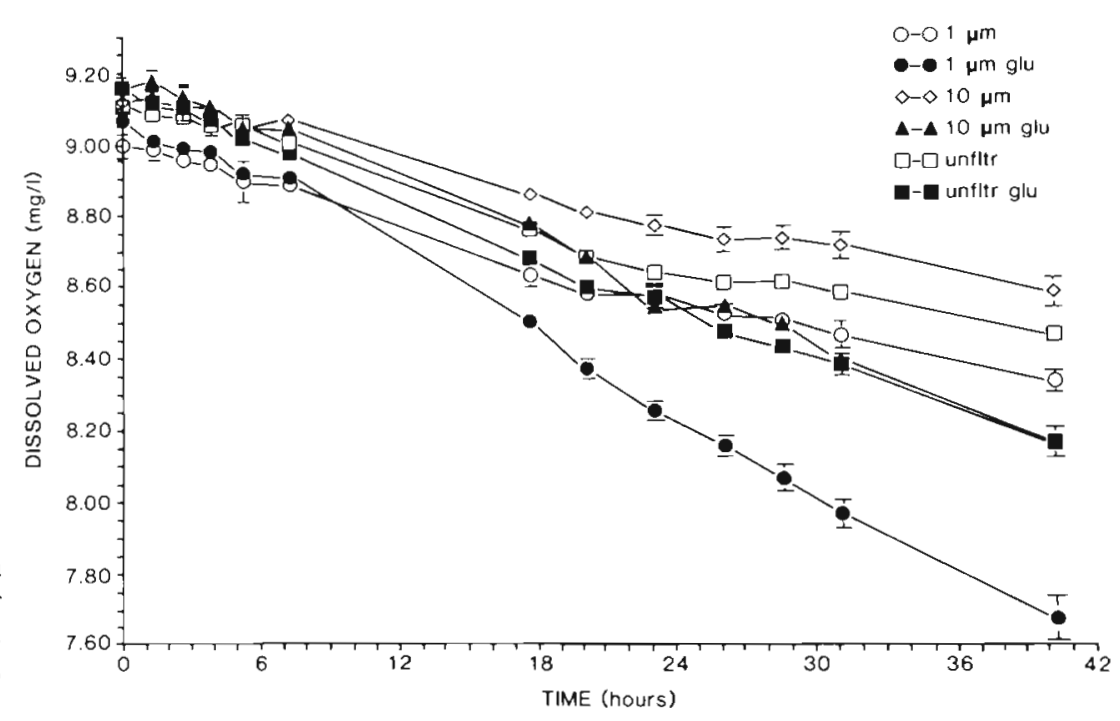


eral pattern observed for all stations. DO concentrations decreased linearly over time, with the greatest decreases occurring in those bottles to which glucose had been added. The effect of glucose addition was clearly evident as slopes of DO versus time were significantly more negative and the final DO concentrations for each amended size fraction were markedly lower than their unamended counterparts. As illustrated in Fig. 2, the rate of oxygen consumption remained constant for $24 \mathrm{~h}$. To demonstrate general patterns attributable to season, size fractionation and substrate amendment, data of the form illustrated in Fig. 2 were grouped into summer and winter periods for the first $24 \mathrm{~h}$ interval.

A number of investigators have found that long-term incubations do not greatly affect the rate of microbial metabolism (e.g. Ogura 1975, Fuhrman \& Azam 1980). Williams (1981) reported that the rate of respiration of Loch Ewe plankton, either fractionated or unfractionated, did not vary for over $48 \mathrm{~h}$, and Pomeroy \& Deibel (1986) showed linear respiration rates of plankton incubated at $4.2^{\circ} \mathrm{C}$ for over $20 \mathrm{~d}$. In our water samples, respiration rates were statistically constant for $24 \mathrm{~h}$, and Sherr, B. F. et al. (1986) with subsamples of water used here found no bacterial growth during the first $12 \mathrm{~h}$ interval in samples with and without eukaryotic inhibitors present. In contrast to these results however, there have been several reports of substantial increases in bacterial numbers in samples incubated for long (h) periods (Ferguson et al. 1984 and references therein). There is no obvious explanation for this inconsistency and it deserves further investigation. We will return to some implications of this finding subsequently.

\section{Oxygen consumption by size fraction}

Respiration by all size classes of plankton was generally highest in the upper reaches of the Duplin River and decreased with increasing distance from the estuary (Figs. 3, 4, and 5). The onshore to offshore difference in respiration was least for the $208 \mu \mathrm{m}$ screening treatment (factor of 1.3) and greatest for the $1 \mu \mathrm{m}$ screening (factor of 4.3). Respiration rates were higher during the warmer months of the year for all size classes of plankton, but the differences were most pronounced for the smallest plankton. In water filtered through $208 \mu \mathrm{m}$ and $10 \mu \mathrm{m}$ screens, rates of respiration during winter were generally 40 to $50 \%$ of summer rates at both estuarine and oceanic sites. However, for the $<1$ um plankton, the difference in respiration between summer and winter periods was greatest in the upper estuary $(4.5: 1)$ and decreased in the offshore direction (2.5:1 and 1.6:1 for 1.6 and $10 \mathrm{~km}$ offshore).

The relative contribution of autotrophic plankton to

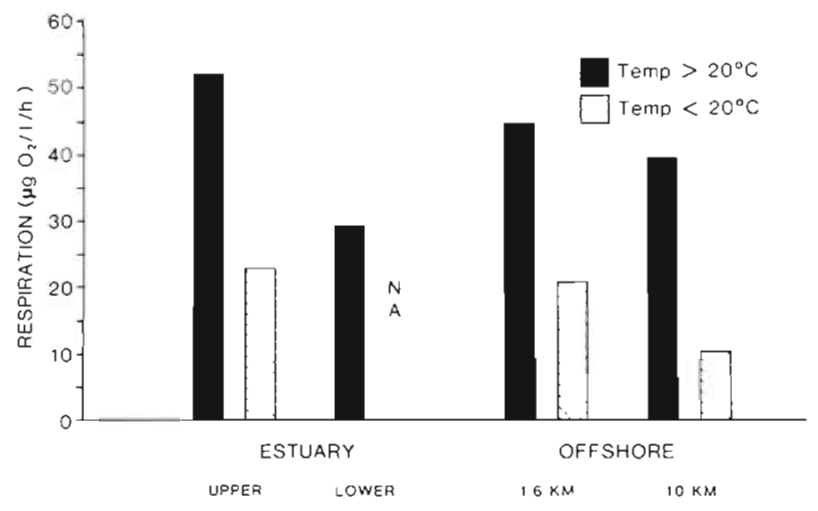

Fig. 3. Average seasonal rates of oxygen consumption in $208 \mu \mathrm{m}$ filtered water at estuarine (upper and lower Duplin River) and nearshore (1.6 and $10 \mathrm{~km}$ offshore) sites. Summer (black) and winter (shaded) refer to intervals when water temperature was above or below $20^{\circ} \mathrm{C}$, respectively. NA: not

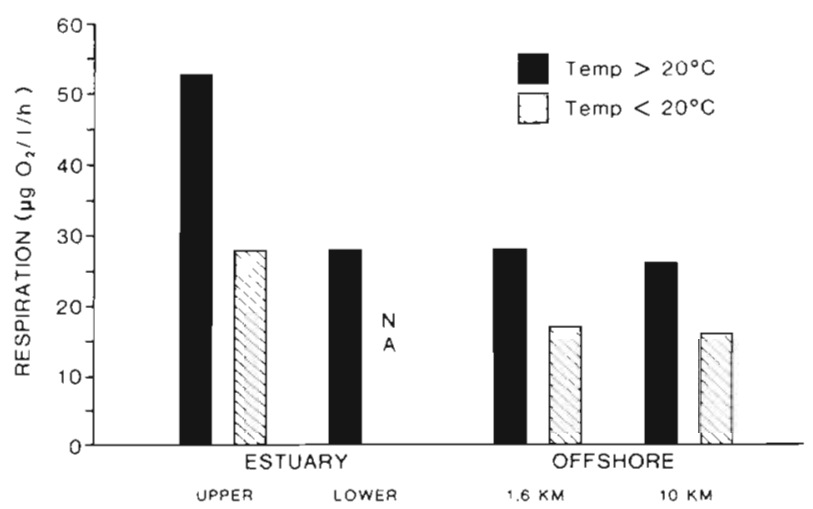

Fig. 4. Mean seasonal rates of oxygen consumption in $10 \mu \mathrm{m}$ filtered water at estuarine and nearshore sites

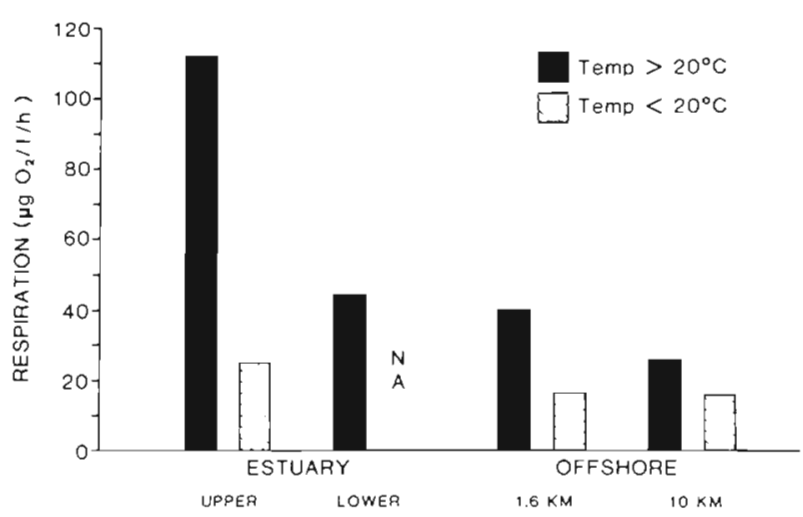

Fig. 5. Mean seasonal rates of oxygen consumption in $1 \mu \mathrm{m}$ filtered water at estuarine and nearshore sites

overall plankton oxygen consumption is negligible. It is estimated (Burris 1980, Peterson 1980) that respiration of photoautotrophs in the estuary and the nearshore region averaged 2.2 and $2.1 \mu \mathrm{g} \mathrm{O}_{2} \mathrm{l}^{-1} \mathrm{~h}^{-1}$, respectively As the average relative contribution to overall primary 
productivity by organisms between 0.45 to $1.0 \mu \mathrm{m}, 1.0$ to $20 \mu \mathrm{m}$ and $>20 \mu \mathrm{m}$ is $<1,55$ and $44 \%$, respectively (Hopkinson unpubl.), the relative contribution of any size class to overall planktonic respiration must be less than $4 \%$.

\section{Total plankton respiration in the Georgia coastal zone}

Plankton respiration is generally much higher in Georgia estuarine environments than in the adjacent nearshore zone (Hopkinson 1985). A comparable pattern was observed in this study. Averaged over the entire year, oxygen consumption in $208 \mu \mathrm{m}$ filtered water declined from $38 \mu \mathrm{g} \mathrm{O}_{2} \mathrm{I}^{-1} \mathrm{~h}^{-1}$ in the upper Duplin River, to $33 \mu \mathrm{g} \mathrm{O} \mathrm{l}^{-1} \mathrm{~h}^{-1} 1.6 \mathrm{~km}$ offshore, to $29 \mu \mathrm{g} \mathrm{O}_{2} \mathrm{l}^{-1}$ $\mathrm{h}^{-1} 10 \mathrm{~km}$ offshore. Although the rate of heterotrophic metabolism in the estuary is comparable to that observed in other very productive estuarine regions (Patten 1961, Taft et al. 1980), the rates measured in the nearshore zone are an order of magnitude higher than in most continental shelf regions (Riley 1941, Christensen \& Packard 1976, Garside \& Malone 1978j.

The high rates of oxygen consumption found in this study are attributable to the overall high level of primary productivity in the coastal Georgia environment. The offshore decline in metabolism is consistent with the hypothesis that total production, including allochthonous organic carbon inputs, is highest in the upper estuary where the water is in intimate contact with the salt marsh and decreases with increasing distance from the marsh. Relatively low rates of plankton respiration in the lower Duplin River may be the result of reduced allochthonous inputs, relative to the upper Duplin, and rates of in situ primary production that are substantially lower than in the nearshore region.

\section{Effect of size fractionation on planktonic respiration}

It was particularly interesting that respiration attributable to organisms passing a $1 \mu \mathrm{m}$ screen exceeded rates in both $10 \mu \mathrm{m}$ filtered water and $208 \mu \mathrm{m}$ filtered water. The pattern of respiration enhancement in the less than $1 \mu \mathrm{m}$ fraction varied considerably from station to station (Fig. 6). Respiration in this fraction exceeded respiration of the $<208 \mu \mathrm{m}$ samples by the largest proportion in the upper estuary $(180 \%)$; this relationship decreased with increasing distance offshore. Similar spatial patterns were evident for the respiration of organisms $<10 \mu \mathrm{m}$ relative to those $<208 \mu \mathrm{m}$ and for organisms $<1 \mu \mathrm{m}$ relative to those $<10 \mu \mathrm{m}$.

Williams (1981), using experimental procedures comparable to ours, reported similar results, with one

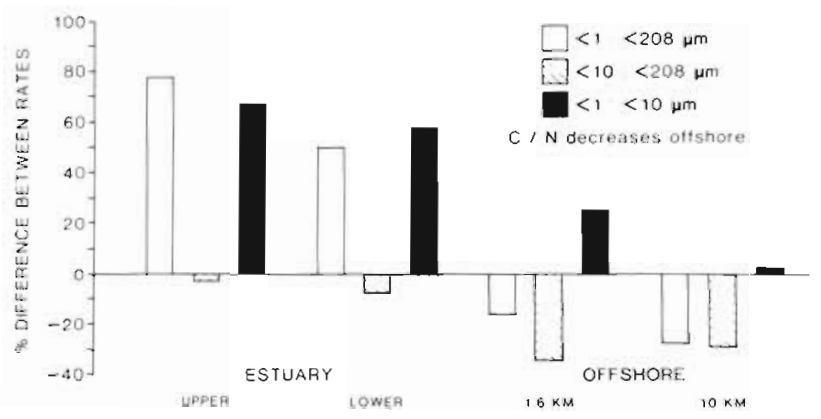

Fig. 6. Time averaged respiration rates by site for each size fraction relative to all other size fractions

notable exception. In both studies, respiration rates were linear in screened samples for tens of hours, the majority of the respiration was associated with the $<10 \mu \mathrm{m}$ size fraction, and $>50 \%$ of the total respiration was attributable to the $<1 \mu \mathrm{m}$ fraction. However, in contrast to our results, Williams (1981) found that respiration of organisms passing a $1 \mu \mathrm{m}$ screen was not elevated; there was no evidence that grazing pressure affected respiration rates in any of the size fractions, while in our study, respiratory activity in $1 \mu \mathrm{m}$ screened water was significantly enhanced.

The question arises as to whether respiration enhancement in $1 \mu \mathrm{m}$ screened water was due to the direct effect of filtration. It has been suggested that cell disruption during filtration can be a major source of inorganic ions and/or organic substrate for bacterioplankton and thus microbial growth rates can be enhanced (Ferguson et al. 1984). To test for a filtration effect, we measured concentrations of 2 potentially important bacterial substrates, ammonium and primary amines, immediately before and after filtering. We also measured the stimulatory effect of direct glucose and ammonium additions on respiration in filtered water. We found no increase in the concentration of $\mathrm{NH}_{4}{ }^{+}$or primary amines following reverse fiitration (Table 1). Nor did additions of $\mathrm{NH}_{4}^{+}$enhance microbial respiration. Large glucose additions $\left(1 \mathrm{mg} \mathrm{l}^{-1}\right)$ did stimulate oxygen consumption in the $<1 \mu \mathrm{m}$ fraction but the amount of glucose added was over an order of magnitude larger than could have been reasonably expected following the disruption of all plankton smaller than either 1 or $10 \mu \mathrm{m}$. The maximum potential increase in substrate concentration following the complete disruption of all bacteria in our samples could be only about $50 \mu \mathrm{g} \mathrm{C} \mathrm{l}^{-1}$ (Bratbak \& Dundas 1984, Sherr pers. comm.). This could support microbial respiration for a maximum of 3 to $4 \mathrm{~h}$. It could not sustain microbial respiration at rates in excess of $180 \%$ of rates for $208 \mu \mathrm{m}$ filtered water for more than $24 \mathrm{~h}$. As the biomass of organisms between 1 and $10 \mu \mathrm{m}$ in size is less than that of organisms passing a $1 \mu \mathrm{m}$ screen (Sherr, B. F. et al. 1986), potential enhancement from their 
Table 1. Effects of reverse flow filtration and respiratory response of bacterioplankton to substrate amendment

\begin{tabular}{|c|c|c|c|c|}
\hline \multirow{3}{*}{$\begin{array}{l}\text { Substrate } \\
\text { Glucose }\end{array}$} & \multicolumn{2}{|c|}{ Respiratory response } & \multicolumn{2}{|c|}{ Concentration } \\
\hline & \multicolumn{2}{|c|}{ control amended } & \multicolumn{2}{|c|}{ unfiltered $\quad$ filtered } \\
\hline & $100 \%$ & $+190-250 \% \quad \cdots$ & \multicolumn{2}{|c|}{ not tested } \\
\hline Ammonium & $100 \%$ & $-93 \%$ & 1.67 & $1.53 \mathrm{NS}$ \\
\hline Primary amines & \multicolumn{2}{|c|}{ not tested } & 0.050 & $0.052 \mathrm{NS}$ \\
\hline \multicolumn{5}{|c|}{$\begin{array}{l}\text { Respiratory responses shown relative to unamended rate. Glucose effect reported as average annual response for nearshore } \\
\text { and estuarine sites, respectively. Ammonium effect tested only once at the upper Duplin River site. Concentration of } \\
\text { ammonium in units of } \mu M \text {, while units for primary amines are relative absorbances with a } 4 \mathrm{~cm} \text { cell. Statistics-paired } t \text {-test, } \\
\text { where NS = not significant }(p>0.05) \text { and } \cdots=\text { significant }(p<0.001)\end{array}$} \\
\hline
\end{tabular}

disruption would be even less than that from microbes smaller than 1 um.

It is unlikely that the respiration enhancement is due to an increase in microbial biomass during incubation in the bottles following predator removal. As discussed previously, the linear nature of oxygen consumption over time in the $<1 \mu \mathrm{m}$ fraction suggests that microbial biomass remained constant for at least $24 \mathrm{~h}$. Furthermore, experiments by Sherr, B. F. et al. (1986), using the same water that we collected from the upper Duplin River station in February and August, showed that bacterial numbers were constant for at least $12 \mathrm{~h}$ (the longest time examined) following the addition of eukaryotic inhibitors to $10 \mu \mathrm{m}$ screened water.

In the past decade it has become increasingly apparent that there can be close trophic interaction between bacteria and phagotrophic nanoplankton. These organisms not only dominate the plankton numerically (Sheldon et al. 1972, Sieburth et al. 1978), but the heterotrophic nanoplankton, i.e. microflagellates and ciliates (Fenchel 1982, Azam et al. 1983, Davis \& Sieburth 1984, Sherr \& Sherr 1984, Sherr, B. F. et al. 1986, Sherr, E. B. et al. 1986) often appear to be the major pelagic grazers of marine bacterioplankton. Changes in the rate of oxygen consumption following selective size fractionation support the concept that there is a high degree of trophic interaction between these groups. In the absence of the majority of their predators (following $1 \mu \mathrm{m}$ filtration) bacterioplankton respiration increased substantially (Figs. 2, 3, 5 and 6). Since there was no evidence that oxygen consumption was enhanced in water samples that had been screened through the $10 \mu \mathrm{m}$ filter, this indicates that close coupling existed between the organisms less than $1 \mu \mathrm{m}$ with those between 1 and $10 \mu \mathrm{m}$, but that coupling was less significant between the latter size group and those organisms between 10 and 208 .m.

\section{Relative contribution by size fraction to overall plankton metabolism}

The contribution by various size classes of plankton to overall plankton metabolism is typically determined by comparing the rate of oxygen consumption by plankton passing various size screens with the rate of oxygen consumption by the entire plankton community. In this study the nominal upper particle size limit was $208 \mu \mathrm{m}$. Consequently, the significance of respiration by the large zooplankton cannot be determined. However, comparisons of oxygen consumption in $300 \mathrm{ml}$ bottles containing $208 \mu \mathrm{m}$ filtered water to respiration measured in $20 \mathrm{l}$ bottles with unfiltered water (Hopkinson 1985) indicate that large plankton contribute less than $10 \%$ of the overall respiration. This is in agreement with observations of respiration by Williams (1981) and of nitrogen regeneration by Harrison (1978), Caperon et al. (1979), and Glibert (1982).

Table 2. Summary of results for short-term models of the planktonic bacterio-microprotozoan system. Time interval of interest is the period required for bacteria in Case \#1 to double their initial biomass. Based on the assumptions stated in the text, this interval is about $0.5 \mathrm{~d}$. Changes are final conditions relative to initial conditions of Case 1. Rates are in carbon units per 2 time intervals ( $24 \mathrm{~h}$ )

\begin{tabular}{|c|c|c|c|c|}
\hline \multirow[t]{2}{*}{ Case number } & \multirow[t]{2}{*}{$\begin{array}{c}\text { Change in } \\
\text { bacterial biomass }\end{array}$} & \multicolumn{2}{|c|}{$\begin{array}{l}\text { Change in } \\
\text { respiration of }\end{array}$} & \multirow[t]{2}{*}{$\begin{array}{l}\text { Mean respiration } \\
\text { Bacteria \& Protozoa }\end{array}$} \\
\hline & & Bacteria & Protozoa & \\
\hline 1 & 0 & 0 & 0 & 44 \\
\hline 2 & $+6(35 \%)$ & $+35 \%$ & - & 52 \\
\hline 3 & $+17(100 \%)$ & $+100 \%$ & - & 50 \\
\hline 4 & 0 & 0 & 0 & 44 \\
\hline 5 & $+17(100 \%)$ & $+100 \%$ & - & 50 \\
\hline
\end{tabular}




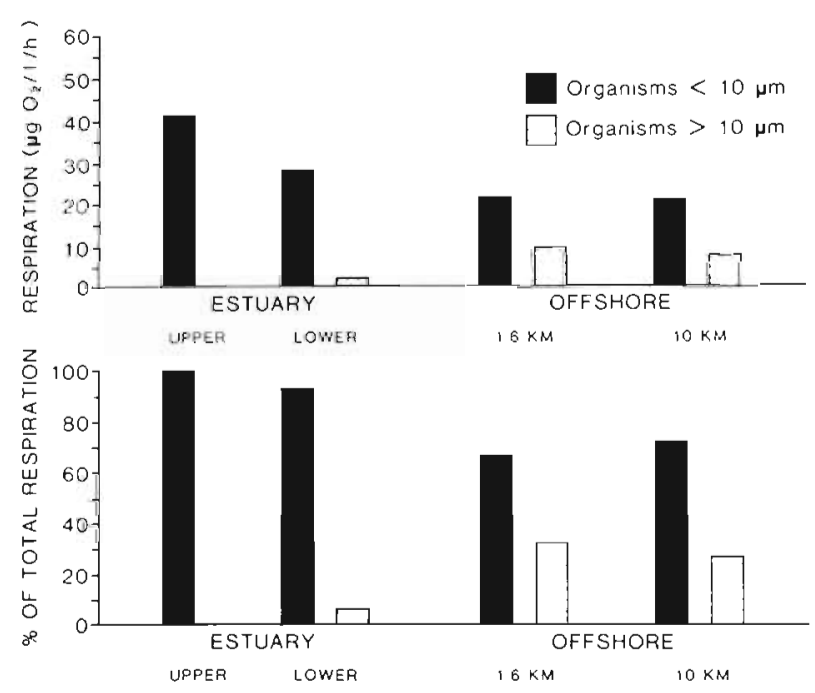

Fig. 7 Time averaged respiration rates of bacterio-microflagellate plankton $(0$ to $10 \mu \mathrm{m}$ ) and microplankton (10 to $208 \mu \mathrm{m})$ for estuarine and nearshore sampling sites. Upper absolute rates $\left(\mu \mathrm{g} \mathrm{O}_{2} \mathrm{l}^{-1} \mathrm{~h}^{-1}\right.$ ); lower: relative importance of each size fraction (percent of the sum of each)

Although changes, induced by separating (albeit not precisely) the bacteria and microprotozoa (BMP) preclude determination of their individual contributions to overall plankton metabolism, it is possible to compare the importance of these organisms to larger plankton in the size range of 10 to $208 \mu \mathrm{m}$. Oxygen consumption of the BMP $(<10 \mu \mathrm{m}$ fraction) was substantially greater than that of the microplankton $(>10 \mu \mathrm{m}$ to $<208 \mu \mathrm{m})$ at all stations, at all times (Fig. 7a). BMP respiration was highest in the upper estuary $\left(41 \mu \mathrm{g} \mathrm{O}_{2} \mathrm{l}^{-1} \mathrm{~h}^{-1}\right)$ and lowest $10 \mathrm{~km}$ offshore $\left(21.2 \mu \mathrm{g} \mathrm{O}_{2} \mathrm{l}^{-1} \mathrm{~h}^{-1}\right)$. In contrast, microplankton oxygen consumption was lowest in the upper estuary $\left(<1 \mu \mathrm{g} \mathrm{O} \mathrm{O}_{2} \mathrm{l}^{-1} \mathrm{~h}^{-1}\right)$ and highest in the ocean $\left(10.7\right.$ and $7.9 \mu \mathrm{g} \mathrm{O}_{2} \mathrm{l}^{-1} \mathrm{~h}^{-1}$ at 1.6 and $10 \mathrm{~km}$ offshore, respectively). Of the total respiration 67 to $\sim 100 \%$ was attributed to the BMP (Fig. 7b). The microplankton contributed much less than the BMP to the total metabolism at all stations, but their relative importance increased from the upper estuary to the offshore region.

The differences in relative importance of BMP and microplankton between the estuary and the nearshore region may reflect differences in the pelagic trophic webs in these 2 regions. In the estuary, respiration measurements show that the microplankton contribute little to the total and consequently the trophic link between these 2 size groups is highly inefficient. However, BMP numbers are maintained within a relatively narrow range seasonally (Fallon et al. 1986, Sherr, B. F. et al. 1986), suggesting that the BMP are being grazed. As estuarine water floods the marsh twice daily, it is likely that the BMP are grazed primarily by the marsh benthic community rather than by the larger plankton.
In contrast, the increased respiratory importance of microplankton in the nearshore suggests that there is significant trophic transfer between the BMP and microplankton.

Explanation for enhanced microbial respiration: comparison of growth and respiration approaches to estimating microbial dynamics

Sherr, B. F. et al. (1986) conducted microbial growth and grazing studies on bacterioplankton and bactivorous nanoplankton in the Duplin River estuary using some of the same water samples employed in this study. With selective screening and eukaryotic inhibitors (which are functionally similar to the $1 \mathrm{um}$ filtered water employed here) to prevent grazing on bacterioplankton, they measured bacterial numbers with time. They observed that decoupling the predatorprey interaction between bacteria and protozoa produced complete inhibition of bacterial growth. Addition of inorganic nitrogen (in the form of $\mathrm{NH}_{4}{ }^{+}$) to parallel sets of eukaryotic inhibited samples however, overcame this inhibition, resulting in a resumption of bacterial biomass production. At first glance, these results seem inconsistent with our respiration data, i.e. (1) the absence of bacterial grazers led to a cessation of bacterial growth but to an enhanced rate of microbial oxygen consumption in the $1 \mu \mathrm{m}$ size-fractionated water and (2) the addition of $\mathrm{NH}_{4}{ }^{+}$had no measurable effect on oxygen consumption but a highly significant effect on bacterial growth rates. However, inhibition of cell division does not necessarily mean that other components of cellular metabolism are not still active. In fact, the oxygen consumption data argue strongly for the existence of enhanced cellular catabolism in the absence of bacterial predators. We believe this is an important consideration. The following section addresses this problem.

\section{Modeling analyses of the planktonic food web}

The apparent inconsistency in growth and respiration responses of microbes following prey removal or ammonium addition is related to the nature of the coupling between bacteria and their protozoan grazers, the carbon to nitrogen ratio of the food source for bacteria and the availability to bacteria of inorganic nitrogen in the water column. We present a general, hypothetical model of the bacterial and nanoplanktonic portion of the pelagic food web to illustrate the basic processes which lead to the seemingly inconsistent growth and metabolic responses of the bacterioplankton (Fig. 8). 


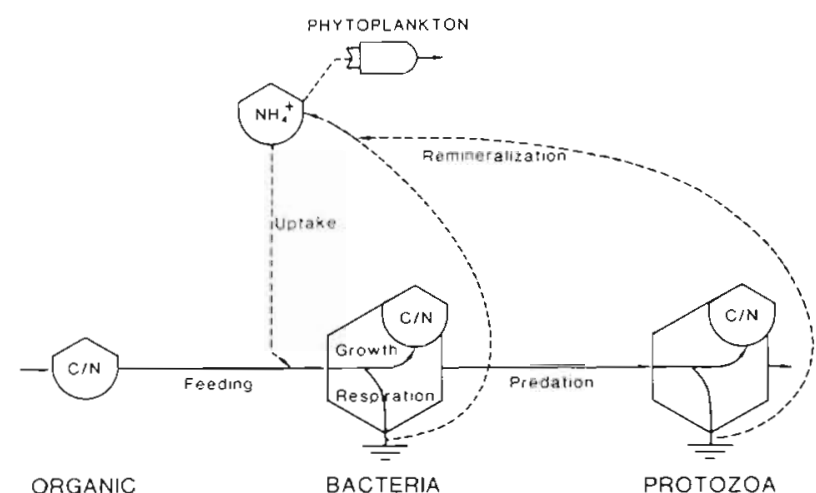

MRGANIS

Fig. 8. Conceptual model of $\mathrm{C}$ and $\mathrm{N}$ flows and of interactions between bacteria and their immediate grazers, the hetero-

trophic nanoplankton, i.e. microprotozoans and ciliates

The simplistic model considers 4 compartments of carbon and nitrogen (organic food source for bacteria, dissolved inorganic nitrogen in the water, bacteria, nanoplankton). The idealized flows connecting compartments represent basic organismal processes including feeding, growth, respiration, predation, nutrient regeneration, and inorganic nutrient uptake.

The model was statically evaluated by 'running' it for one bacterial biomass doubling time under favorable coastal Georgia conditions (sufficient substrate was provided to allow biomass to double with an initial growth efficiency of $33 \%$ ). Initial biomasses of bacteria and nanoplankton were determined from Sherr, B. F. et al. (1986). Stoichiometry of $\mathrm{C}$ to $\mathrm{N}$ in protoplasm was held constant at 6:1 (Redfield et al. 1963). Nutrient limitation was modeled by preventing bacteria from taking up inorganic nitrogen. Growth efficiency was initialized at $33 \%$ for both bacteria and nanoplankton.

To demonstrate the processes leading to what appeared to be inconsistencies between the growth and respiration studies, we present the results of 'simulations' in which the $\mathrm{C} / \mathrm{N}$ ratio of the bacterial food source was varied between a nominal $6: 1$ and 100:1 (Table 3). In the model, bacteria respond to an increase in the C/N ratio of their food (Rows $1 \& 2$ ) in 3 ways: (1) a greater percentage of assimilated carbon is lost through respiration, i.e. carbon mineralization increases while growth efficiency decreases (Rows 5 \& 7), (2) $N$ efficiency increases and $N$ remineralization decreases (Rows 6 \& 8), and (3) bacterial biomass production decreases (Row 3).

These microbial responses simulated in the model have been demonstrated experimentally in a variety of environments. In detritus-based systems where organic matter often has a high ratio of carbon to nitrogen, bacteria can employ a number of mechanisms to maintain a constancy in tissue $\mathrm{C} / \mathrm{N}$ stoichiometry, including immobilization of inorganic nitrogen, reduction in the carbon assimilation efficiency and an increase in the nutrient assimilation efficiency. In detrital grassland systems, bacteria can immobilize inorganic nitrogen available in the soil solution when degrading organic material with a high ratio of carbon to nitrogen (Cole-

Table 3. Simulation results of a conceptual model of the bacterial-nanoplanktonic portion of the pelagic food web. Results illustrate population growth and metabolic responses to varying $\mathrm{C} / \mathrm{N}$ ratios of the bacterial food source. The model is calculated with the assumption that inorganic $\mathrm{N}$ is limiting and hence unavailable for uptake by bacteria

\begin{tabular}{|lccccccccc}
\hline Substrate C:N & 61 & $9: 1$ & $12: 1$ & $15: 1$ & $18: 1$ & $30: 1$ & $50 \cdot 1$ & 100 & 1 \\
N relative to 54 C & 54.9 & $54 \cdot 6$ & 54.4 .5 & $54 \cdot 3.6$ & $54: 3$ & $54: 1.8$ & 54.1 .1 & $54: 0.54$ \\
Bacterial C production & 18 & 18 & 18 & 18 & 18 & 10.8 & 6.6 & 3.24 \\
Bact N production & 3 & 3 & 3 & 3 & 3 & 1.8 & 1.1 & 0.54 \\
Bact C mineralization & 36 & 36 & 36 & 36 & 36 & 43 & 47.4 & 51 \\
Bact N mineralization & 6 & 3 & 1.5 & 0.6 & 0 & 0 & 0 & 0 \\
Bact growth efficiency & $33 \%$ & $33 \%$ & $33 \%$ & $33 \%$ & $33 \%$ & $20 \%$ & $12 \%$ & $5 \%$ \\
Nanoplankton C production & 6 & 6 & 6 & 6 & 6 & 6 & 6 & 6 \\
Nano N production & 1 & 1 & 1 & 1 & 1 & 1 & 1 \\
Nano C mineralization & 12 & 12 & 12 & 12 & 12 & 7.1 & 4.4 & 2.1 \\
Nano N mineralization & 2 & 2 & 2 & 2 & 2 & 1.2 & 0.73 & 0.36 \\
Total C mineralized & 48 & 48 & 48 & 48 & 48 & 50.1 & 51.8 & 53.1 \\
Percent bacterial & $75 \%$ & $75 \%$ & $75 \%$ & $75 \%$ & $75 \%$ & $85 \%$ & $92 \%$ & $96 \%$ \\
Percent nanoplanktonic & $25 \%$ & $25 \%$ & $25 \%$ & $25 \%$ & $25 \%$ & $15 \%$ & $8 \%$ & $4 \%$ \\
Total N mineralized & 8 & 5 & 3.5 & 2.6 & 2 & 1.2 & 0.73 & 0.36 \\
Percent bacterial & $75 \%$ & $60 \%$ & $42 \%$ & $38 \%$ & $0 \%$ & $10 \%$ & $0 \%$ & $0 \%$ \\
Percent nanoplanktonic & $25 \%$ & $40 \%$ & $58 \%$ & $62 \%$ & $100 \%$ & $100 \%$ & $100 \%$ & $100 \%$ \\
Degree to which: & & & & & & $89 \%$ & $93 \%$ & $95 \%$ & $93 \%$ \\
Bact \& nano are C sink & $89 \%$ & $89 \%$ & $89 \%$ & $89 \%$ & $89 \%$ & $4 \%$ & $2 \%$ \\
Bact \& nano are C link & $11 \%$ & $11 \%$ & $11 \%$ & $11 \%$ & $11 \%$ & $7 \%$ & $4 \%$ \\
\end{tabular}


man et al. 1983). In a study of bacterial degradation of estuarine macrophytic material, it was shown that bacterial growth efficiency decreases as the ratio of carbon to nitrogen in the organic substrate increases (Linley \& Newell 1984). Goldman et al. (1987a) reported that microflagellates also possess the ability to metabolically adapt to high $\mathrm{C} / \mathrm{N}$ ratio food sources. They showed that the microflagellate Paraphysomonas imperforata can produce biomass with a specific stoichiometry over a wide range of prey $\mathrm{C} / \mathrm{N}$ ratios by varying its nutrient assimilation efficiency.

The results of both experimental and modeling work are entirely consistent. In experimental work in the estuary, the $\mathrm{C} / \mathrm{N}$ ratio of the bacterial food source was high due to the importance of allochthonous inputs of macrophytic detritus from the salt marsh and dissolved inorganic nitrogen was in short supply (Haines \& Dunstan 1975, Wheeler 1976, Hopkinson 1987). By isolating bacteria from their nanoplanktonic grazers, the inorganic nitrogen regenerated by nanoplankton was, by definition, no longer available to the bacteria to supplement the $N$ deficient detrital material they were degrading. Experimentally and in simulation, in the absence of a regenerative flow of $\mathrm{N}$, bacterial growth slowed while respiration increased. Carbon has to be selectively catabolized until sufficient $N$ is obtained to produce biomass with a $6: 1 \mathrm{C} / \mathrm{N}$ stoichiometry. Addition of ammonium to filtered or inhibited samples is functionally similar to having either the $\mathrm{N}$ regenerating nanoplankton present or to lowering the $\mathrm{C} / \mathrm{N}$ ratio of the bacterial food source (high $\mathrm{C} / \mathrm{N}$ food plus inorganic $\mathrm{N}$ is equivalent to low $\mathrm{C} / \mathrm{N}$ food). The model showed that as the percentage of $\mathrm{N}$ in the food increased $(\mathrm{C} / \mathrm{N}$ decreased), bacterial growth increased, growth efficiency increased and respiratory losses decreased. Experimentally, when $\mathrm{N}$ was added to the $1 \mu \mathrm{m}$ filtered or inhibited water, bacterial growth increased while bacterial respiration remained constant. Growth can increase while respiration remains constant if bacterial growth efficiency also increases. Thus, although the bacterial population increased (growth), with an increase in bacterial growth efficiency, total respiration of the increasingly larger population of bacteria can remain constant. As illustrated in Fig. 6, the degreee of stimulation of respiration in the $1 \mu \mathrm{m}$ filtered water decreased in the offshore direction. $\mathrm{C} / \mathrm{N}$ ratios of the suspended organic matter decline substantially in the offshore direction, reflecting the decreasing importance (or abundance) of salt marsh macrophytic detritus in the offshore region (Hopkinson 1985). Presumably, as the $\mathrm{N}$ quality of the organic matter improved, the bacterial conversion efficiency or growth efficiency increased so that the regenerative flow of $\mathrm{N}$ by grazers became less important.

Results of this simplistic model closely parallel those obtained from experimental measures of respiration and growth. Both the experimental and modeling analyses showed that bacterial respiration increased following removal of nanoplankton when the bacterial food source was low in $\mathrm{N}$ and dissolved inorganic nitrogen unavailable. Experimentally it was found that increased respiration was not accompanied by, or due to, increased numbers of bacteria in incubation chambers. Rather as suggested by the model, increased respiration and decreased bacterial growth efficiency was due to a lack of available $\mathrm{N}$ in both food and the external medium. Experimentally it was found that ammonium addition to bacterial incubations did not increase respiration of the entire population but did lead to an increase in the number of bacteria (resumption of growth). While this latter result seemed inconsistent initially, the model suggested that with bacterial growth becoming more efficient when $\mathrm{N}$ was available, bacterial numbers could increase while respiration of the larger population remained unchanged relative to the nominal case.

There has been much discussion recently concerning the relative importance of bacteria versus microprotozoans as agents of nitrogen recycling in the sea (e.g. Goldman \& Caron 1985). Further examination of the results of the model illustrates the importance of food source $\mathrm{C} / \mathrm{N}$ stoichiometry in determining not only the relative role of bacteria and nanoplankton in $N$ remineralization but also the overall trophic efficiency of the microbial loop (Table 3, Figs. 9 and 10). The model indicates that the relative importance of bacteria as agents of $N$ remineralization decreases as the $\mathrm{C} / \mathrm{N}$ ratio increases. The experimental work of Goldman et al. (1987b) on bacterial gross growth efficiency and ammonium regeneration supports this conclusion as

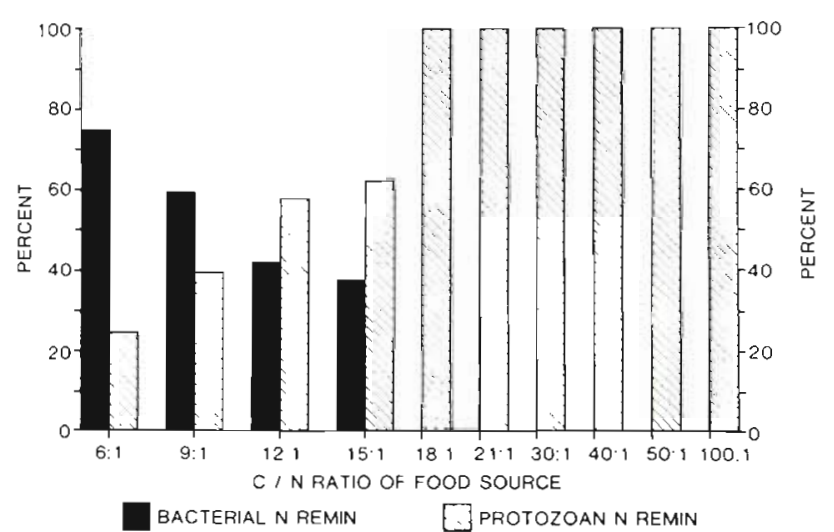

Fig. 9. Model results illustrating the shift in relative importance in nitrogen remineralization from primarily bacteria to solely nanoplankton as the $\mathrm{C} / \mathrm{N}$ ratio of the bacterial food source increases from $6: 1$ to 100.1 . This is based on the assumption that inorganic $\mathrm{N}$ is unavailable for bacterial uptake 


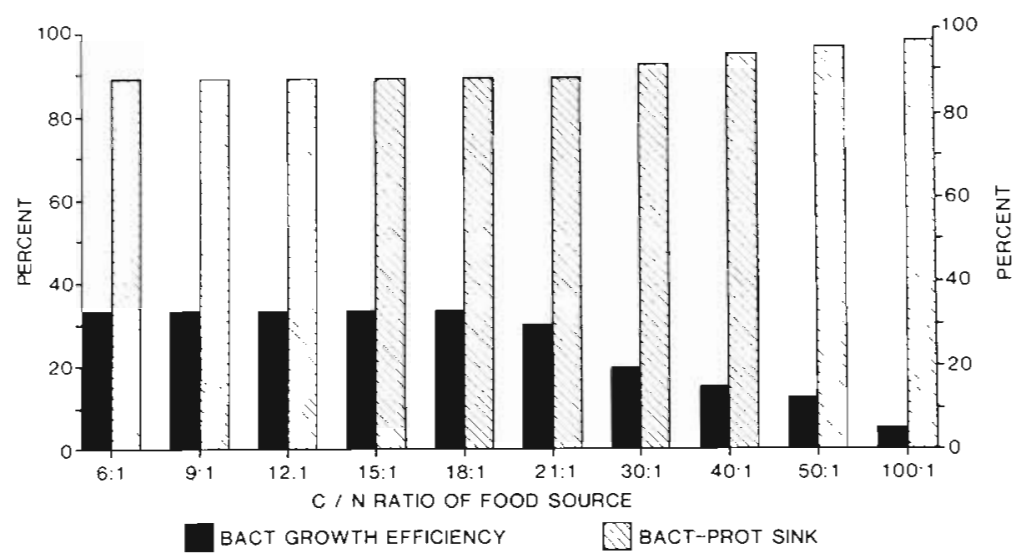

Fig. 10. Model results illustrating the importance of the $\mathrm{C} / \mathrm{N}$ ratio of the bacterial food source as it affects both bacterial growth efficiency and overall trophic efficiency of the 'microbial loop' Results are based on the assumption of inorganic $\mathrm{N}$ limitation they found that efficiency and regeneration decreased as the $\mathrm{C} / \mathrm{N}$ ratio of the substrate increased. From the model it can be seen that bacteria are the most important remineralizers only at low $\mathrm{C} / \mathrm{N}$ ratios. Nanoplankton are of equal importance when the $C / N$ ratio is about $11: 1$, and by $18: 1$ they remineralize up to $100 \%$ of the total. At $\mathrm{C} / \mathrm{N}$ ratios above $18: 1$, bacteria will potentially be net immobilizers of dissolved inorganic $\mathrm{N}$ and compete with autotrophs for a nutrient which is usually in critically short supply. It was mentioned earlier that as the $\mathrm{C} / \mathrm{N}$ ratio of bacterial food increased, the bacterial conversion efficiency decreased from the nominal $33 \%$ at $6: 1$ to $4 \%$ at $100: 1$. The net effect of organic matter quality, as indicated by $\mathrm{C} / \mathrm{N}$ ratios, on the overall trophic efficiency of the bacterioplanktonnanoplanktonic assemblage within the microbial loop is to decrease the transfer of $\mathrm{C}$ to higher levels as the $\mathrm{C} /$ $\mathrm{N}$ ratio increases. Whereas $11 \%$ of the $\mathrm{C}$ entering the microbial loop with a $\mathrm{C} / \mathrm{N}$ of $6: 1$ potentially passes through to larger organisms, at a $\mathrm{C} / \mathrm{N}$ of $50: 1$ or $100: 1$, less than $3 \%$ can potentially pass to higher trophic levels.

\section{CONCLUSIONS AND FISHERIES RAMIFICATIONS}

We believe these results may partially explain the relatively depauperate benthic biomass and low fisheries harvest of the Georgia Bight (Fallon \& Hopkinson 1986, NMFS 1986). As discussed by Hanson et al. (1981), the fauna on the shelf in the Georgia Bight is less abundant than one might expect, given the local production and the outwelling of production from rivers and salt marsh estuaries. We believe that the high level of activity of the microbial loop in the Georgia Bight may be contributing to these conditions. We have shown that the microbial loop is highly active. Given an average respiration of $33 \mu \mathrm{g} \mathrm{O}_{2} \mathrm{l}^{-1} \mathrm{~h}^{-1}$ over all stations at all times and an average depth of $5 \mathrm{~m}$, this amounts to over $540 \mathrm{~g} \mathrm{C} \mathrm{m}^{-2} \mathrm{yr}^{-1}$ directly respired to $\mathrm{CO}_{2}$ (assuming $\mathrm{RQ}=1$ ). As this level of microbial respiration is at least equal to, but generally considerably greater than, aquatic primary production in either the estuary or the nearshore region, it indicates that in addition to in situ production, a substantial amount of organic matter exported from the rivers and marshes must also be respired away and lost from the food web. Along a separate line or reasoning, it has been suggested by several authors (e.g. Azam et al. 1983, Hagström \& Larsson 1984, Sherr \& Sherr 1984), that the mineralization of inorganic nutrients via the microbial loop may stimulate primary production of algae and thus stimulate carbon fixation. In waters off Georgia however, due to the prevalence of high $\mathrm{C} / \mathrm{N}$ ratio detrital material, the microbes may actually be competing with phytoplankton for inorganic nutrients. Thus the potential benefit may not be realized. The possible benefit of any potential nutrient release would further be diminished due to the high suspended solids levels in the water column of the Georgia coastal zone which greatly reduce light levels.

To describe the microbial loop as either a source or sink for organic carbon in pelagic systems is overly simplistic. In coastal Georgia waters, detritus represents a significant percentage of total suspended organic carbon. Incorporation of most of this material into the trophic web must be mediated by microbes. Consequently, although the ecological growth efficiency of the microbial loop community may be low, the loop probably represents a source of biomass for larger metazoans (Sherr, B. F. et al. 1986) by providing organic matter for the latter which would not be available if the microbial loop was inactive. A quantitative assessment of the relative amount of organic carbon made available to larger metazoans from both a direct grazing food chain and the microbial loop remains to be evaluated. Thus, with respect to the pelagic trophic web, the microbial loop may be both a source, in the sense that it may provide food for larger metazoans and a sink, in the sense that a very great percentage of the 
organic carbon that enters the microbial loop may be lost as respiratory $\mathrm{CO}_{2}$. This system is then an antithesis of that described by Pomeroy \& Deibel (1986) who proposed that the reduction of the microbial loop in boreal waters is a major factor in the presence of large-scale fisheries.

Acknowledgements. The authors express their appreciation to several individuals who assisted with this study either in the field, the lab or the darkroom, including Nina Hopkinson, Marc Pipas, Steve Kipp and Eileen Hedick. This manuscrupt has benefitted from the helpful and constructive criticism of Robert Fallon, Robert Christian, P. Williams and 2 anonymous reviewers

\section{LITERATURE CITED}

Azam, F., Fenchel, T., Field, J. G., Meyer-Reil, L. A., Thingstad, T. (1983). The ecological role of watercolumn microbes in the sea. Mar. Ecol. Prog. Ser. 10: 257-263

Berman, $T$ (ed.) (1988). The role of microorganisms in aquatic ecosystems. Hydrobiologia Vol. 159. Dr W. Junk Publishers, Dordrecht, Netherlands

Bratbak, G., Dundas, J. (1984). Bacterial dry matter content and biomass estimations. App. environ. Microb. 48: 755-757

Burris, J. F. (1980). Respiration and photorespiration in marine algae. In: Falkowski, P. G. (ed.) Primary productivity in the sea. Plenum Press, New York, p. 411-432

Caperon, J., Schell, D., Hirota, J., Laws, E. (1979). Ammonium excretion rates in Kaneohe Bay, Hawail, measured by a $15 \mathrm{~N}$ isotope dilution technique. Mar Biol. 54: 33-40

Christensen, J. P., Packard, T T (1976). Oxygen utilization and plankton metabolism in a Washington fjord. Estuar coast. mar Sci. 4: 339-347

Coleman, D. C., Reid, C., Cole, C. (1983). Biological strategies of nutrient cycling in soil systems. Adv. Ecol. Res. 13: 1-55

Cushing, D. H., Walsh, J. (1976). The ecology of the seas. Blackwell Sci. Publ., Oxford

Davis, P. G., Sieburth, J. (1984). Estuarine and oceanic microflagellate predation of actively growing bacterial: estimation by frequency of dividing-divided bacteria. Mar Ecol. Prog. Ser. 19: 237-246

Ducklow, H., Hill, S. (1985). The growth of heterotrophic bacteria in the surface waters of warm core rings. Limnol. Oceanogr. 30: 239-259

Fallon, R. D., Newell, S. Y., Sherr, B., Sherr, E. (1986). Factors affecting bacterial biomass and growth in the Duplin River estuary and coastal Atlantic Ocean. Actes de Colloq. 3: $137-145$

Fallon, R. D., Hopkinson, C. (1986). Community metabolism and nutrient fluxes at Gray's Reef National Marine Sanctuary. NOAA technical report series OCRM/SPD. Department of Commerce, Washington, D. C

Fenchel, T. (1982). Ecology of heterotrophic microflagellates IV Quantitative occurrence and importance as bacterial consumers. Mar Ecol. Prog. Ser. 9: 35-42

Ferguson, R. L., Buckley, E. N., Pallumbo, A. V. (1984). Response of marine bacterioplankton to differential filtration and confinement. Appl. environ. Microb. 47 49-55

Frankenburg, D. (1976). Oxygen in a tidal river: low tide concentration correlates linearly with location. Estuar coast. Shelf Sci. 4: 455-460

Fuhrman, J. A., Azam, F. (1980). Bacterioplankton secondary production estimates for coastal waters of British Colum- bia, Antarctica and California. Appl. environ. Microbiol 39: $1085-1095$

Garside, C., Malone, T. C. (1978). Monthly oxygen and carbon budgets of the New York Bight Apex. Estuar. coast. mar Sci. 6: 93-104

Glibert, P. M. (1982). Regional studies of daily, seasonal and size fraction variabllty in ammonium remineralization. Mar Biol. 70: 209-222

Goldman, J. C., Caron, D. A. (1985). Experimental studies on an omnivorous microflagellate: implications for grazing and nutrient regeneration in the marine microbial food chain. Deep Sea Res. 32: 899-915

Goldman, J. C., Caron, D., Dennett, M. (1987a). Nutrient cycling in a microflagellate food chain: IV Phytoplanktonmicroflagellate interactions. Mar. Ecol. Prog. Ser. 38: $75-87$

Goldman, J. C., Caron, D., Dennett, M. (1987b). Regulation of gross growth efficiency and ammonium regeneration in bacteria by substrate $C: N$ ratio. Limnol. Oceanogr. 32 (6): $1239-1252$

Grasshoff, K. (1983). Methods of seawater analysis. Verlag Chemie, New York

Griffith, P. C. (1988). A high-precision respirometer for measuring small rates of change in the oxygen concentration of natural waters. Limnol. Oceanogr. 33: 624-637

Hagström, A., Larsson, U., Horstedt, P., Normark, S. (1979). Frequency of dividing cells, a new approach to the determination of bacterial growth rates in aquatic environments. Appl. environ. Microbiol. 37: 805-812

Hagström, A., Larsson. U. (1984). Diel and seasonal variation in growth rates of pelagic bacteria. In: Hobbie, J., Williams, P. J. LeB. (eds.) Heterotrophic activity in the sea. Plenum Press, New York, p. 249-262

Haines, E. B. Dunstan, W (1975). The distribution and relation of particulate organic matter and primary productivity in the Georgia Bight. Estuar. coast. mar. Sci. 3: 431-441

Hanson, R., Tenore, K., Bishop, S., Chamberlain, C., Pamatmat, M., Tietjen, J. (1981). Benthic enrichment in the Georgia Bight related to Gulf Stream intrusions and estuarine outwelling. J. mar. Res. 39: 417-441

Harrison, W. G. (1978). Experimental measurement of nitrogen remineralization in coastal waters. Limnol. Oceanogr 23: 684-694

Hobbie, J., Williams, P. LeB. (eds.) (1984). Heterotrophic activity in the sea. Plenum Press, New York

Hopkinson, C. S. (1985). Shallow-water benthic and pelagic metabolism: evidence of heterotrophy in the nearshore Georgia Bight. Mar Biol. 87: 19-32

Hopkinson, C. S. (1987). Nutrient regeneration in shallowwater sediments of the estuarine plume region of the nearshore Georgia Bight, USA. Mar. Biol. 94: 127-142

Hopkinson, C. S., Hoffman, F. A. (1984). The estuary extended - a recipient-system study of estuarine outwelling in Georgia. In: V. Kennedy (ed.) The estuary as a filter. Academic Press, New York, p. 313-330

Imberger, J., Berman, T., Christian, R., Sherr, E., Whitney, D. Pomeroy, L., Wiegert, R., Wiebe, W. (1983). The influence of water motion on the distribution and transport of materials in a salt marsh estuary. Limnol. Oceanogr. 28: 201-214

Linley, E. A. S., Newell, R. C. (1984). Estimates of bacterial growth yields based on plant detritus. Bull. mar. Sci. 35: $409-425$

Moriarty, D. (1984). Measurements of bacterial growth rates in some marine systems using the incorporation of tritiated thymidine into DNA. In: Hobbie, J., Williams, P. LeB. (eds.) Heterotrophic activity in the sea. Plenum Press, New York, p. $217-232$ 
NMFS (1986). Fisheries of the United States, 1985. National fishery statistics program (F/S 21). Current fishery statistics No. 8380 . U.S. Department of Commerce, Washington, D. C.

North, B. B. (1975). Primary amines in California coastal waters: utilization by phytoplankton. Limnol. Oceanogr. 20: $20-27$

Ogura, N. (1975). Further studies on the decomposition of dissolved organic matter in coastal waters. Mar Biol. 31: $101-111$

Pace, M., Glasser, J. Pomeroy, L. (1984). A simulation analysis of continental shelf food webs. Mar Biol 82: 47-63

Patten, B. C. (1961). Plankton energetics of Raritan Bay. Limnol. Oceanogr. 6: 639-387

Petersen, B. J. (1980). Aquatic primary productivity and the ${ }^{14} \mathrm{CO}_{2}$ method: a history of the productivity problem. A. Rev. Ecol. Syst. 11: 359-385

Pomeroy, L. P. (1974). The ocean's food web, a changing paradigm. BioSci. 24: 499-504

Pomeroy, L. R., Wiegert, R. G. (eds.) (1981). Ecosystem and population ecology of a Salt Marsh: a synthesis. SpringerVerlag, New York

Pomeroy, L., Deibel, D. (1986). Temperature requlation of bacterial activity during the spring bloom in Newfoundland coastal waters. Science 233: 359-361

Redfield, A. C., Ketchum, B., Richards, F. (1963). The influence of organisms on the composition of seawater. In: Hill, M. (ed.) The sea, Vol. 2. Interscience, New York, p. 26-77

Riley, G. A. (1941). Plankton studies. III. Long Island Sound. Bull. Bingham oceanog. Coll. 7: 1-93

Sheldon, R. W., Prakash, A., Sutcliffe, W. H. (1972). The size distribution of particles in the ocean. Limnol. Oceanogr. 17: $327-340$

Sherr, B. F., Sherr, E. B. (1984). Role of heterotrophic protozoa in carbon and energy flow in aquatic ecosystems. In: Klug, M., Reddy, C. (eds.) Microbial ecology. American Society for Microbiology, Washington, D. C., p. 412-423

Sherr, B. F., Sherr, E., Andrew, T., Fallon, R., Newell, S. (1986). Trophic interactions between heterotrophic protozoa and bacterioplankton in estuarine water analyzed with selective metabolic inhibitors. Mar. Ecol. Prog. Ser. 32: 169-179

Sherr, E. B., Sherr, B., Fallon, R., Newell, S. (1986). Small aloricate ciliates as a major component of the marine heterotrophic nanoplankton. Limnol. Oceanogr. 31: $177-183$

Sieburth, J. M., Smetacek, V., Lenz, J. (1978). Pelagic ecosys- tem structure: heterotrophic compartments of the plankton and their relationship to plankton size fractions. Limnol. Oceanogr 23: 1256-1263

Smith, D. F., Horner, S. (1982). Laboratory and field measurements of aquatic productivity made by a minicomputer employing a dual oxygen electrode system. Mar Biol. 72: 53-60

Sokal, R. R., Rohlf, F. J. (1969). Biometry. W H. Freeman and Co., San Francisco

SPSS, Inc. Users Manual. Chicago, Illinois

Steele, J., Frost, B. (1977). The structure of plankton communities. Phil. Trans. R. Soc., Ser. B. 280: 485-534

Taft, J. L., Taylor, W. R., Hartwig, E. O., Loftus, R. (1980). Seasonal oxygen depletion in Chesapeake Bay. Estuaries 3: $242-247$

Thomas, J. P. (1966). The influence of the Altamaha River on primary production beyond the mouth of the river. $\mathrm{M}$. S. thesis, University of Georgia, Athens, GA

Wheeler, J. (1976). Fractionation by molecular weight of organic substances in Georgia coastal water. Limnol. Oceanogr. 21: 846-852

Wiebe, W. J., Smith, D. (1977). Direct measurement of dissolved organic carbon release by phytoplankton and incorporation into microheterotrophs. Mar. Biol. 42: 213-223

Wiegert, R. W. Wetzel, R. L. (1979). Simulation experiments with a fourteen-compartment model of a Spartina salt marsh. In: Dame, R. (ed.) Marsh-estuarine systems simulation. University of South Carolina, Columbia, SC, p. 7-39

Williams, P. J. LeB. (1981). Microbial contribution to overall marine plankton metabolism: direct measurements of respiration. Oceanologica Acta 4: 359-364

Williams, P. J. LeB. (1984). A review of measurements of respiration rates of marine plankton populations. In Hobbie, J., Williams, P. LeB. (eds.) Heterotrophic activity in the sea. Plenum Press, New York, p. 357-390

Williams, P. J. LeB., Jenkinson, N. (1982). A transportable, microprocessor-controlled precise Winkler titration suitable for field station and shipboard use. Limnol. Oceanogr 27: $576-584$

Wright, R. (1984). Dynamics of pools of dissolved organic carbon, pages 121-154. In: Hobbie, J., Williams, P. LeB (eds.) Heterotrophic activity in the sea. Plenum Press, New York, p. 121-154

Wright, R., Coffin, R. (1984). Measuring microzooplankton grazing on planktonic marine bacteria by its impact on bacterial production. Microb. Ecol. 10: 137-149 